\title{
BIOCHEMICAL HETEROGENEITY OF ORNITHINE CARBAMOYL TRANSFERASE(OCT) IN PATIENTS WITH OCT DEFICIENCY
}

\author{
Ichiro Matsuda, ${ }^{1}$ Noriyuki NaGata, ${ }^{1}$ Kazuhiko Ohyanagi, ${ }^{2}$ \\ Akira TsuchiYama, ${ }^{2}$ Hiroko Yamamoto, ${ }^{3}$ Yutaka HaSe, ${ }^{3}$ \\ Hiroko KodAMA, ${ }^{4}$ and Yumiko $\mathrm{KAI}^{5}$ \\ ${ }^{1}$ Department of Pediatrics, Kumamoto University Medical School, Kumamoto 860, Japan \\ ${ }^{2}$ Department of Pediatrics, Sapporo Medical College, Sapporo 060, Japan \\ ${ }^{3}$ Department of Pediatrics, Osaka City Children's Medical Center, Osaka 537, Japan \\ ${ }^{4}$ Department of Pediatrics, Jichi Medical College, Tochigi 329-04, Japan \\ ${ }^{5}$ Department of Child Development, Kumamoto University Medical School, \\ Kumamoto 860, Japan
}

\begin{abstract}
Summary The biochemical heterogeneity of ornithine carbamoyltransferase (OCT) was investigated in one male and three female patients with OCT deficienty. OCT from the male patient showed extremely low activity and no immunologically cross-reactive material (CRM) against antihuman liver OCT antibody. Residual OCT in two female patients was similar, being approximately $10 \%$ of the control with regard to both the activity and the amount of CRM. Their kinetic parameters were identical to those of the control. The enzyme activity and amount of CRM in the last female patient were $22.5 \%$ and $48.5 \%$ of the control, respectively. Thus, it is likely that gene mutation caused a reduction of enzyme protein or production of a distinctly unstable enzyme in the former three patients and a structural gene mutation produced a mutant OCT in the last patients.
\end{abstract}

\section{INTRODUCTION}

Ornithine carbamoyltransferase [EC 2.1.3.3] (OTC) is the second sequential enzyme in the urea cycle and located in the mitochondrial matrix of hepatocytes (Snodograss, 1981). Congenital OCT deficiency (McKusick, \#3125) is a disease showing X-linked inheritance (McKusick, 1983) and appears to be most common in five genetically determined urea cycle disorders in man (Walser, 1983). Generally, the clinical pictures in affected male show rapid progress through coma to death within the first month of life. And female patients who are heterozygous are asymptomatic or have variable symptoms which may not become manifest until later infancy or until the second year of life (Shih, 1976; Walser, 1983)! Such vari- 
ation in the clinical manifestations of the OCT deficiency are compatible with genetic heterogeneity and depend on residual activity. Recently, an immunochemical method has been employed for elucidating the nature of the mutant enzyme. In the present study, we used anti-human liver OCT antibody to clarify the biochemical heterogeneity of the affected enzyme in one male and three female patients with OCT deficiency, each from a different family.

\section{CASES REPORTS}

Case 1. This patient was the first male child of healthy Japanese parents. $\mathrm{He}$ was born after a normal pregnancy and delivery. His birth weight was $3,350 \mathrm{~g}$. The first male cousin on his mother's side suffered from the same disease. At 7 days of life, the patient developed seizure, cyanosis and an apnea attack. On admission, the serum ammonia level was $400 \mu \mathrm{g} / \mathrm{dl}$. Exchange blood transfusion and repeated peritoneal dialysis were not effective and at 28 days of life the patient died. Enzyme analysis of autopsied liver tissue disclosed a deficiency of OCT and normal levels of other urea cycle enzymes. The rest of the sample was stored at $-80^{\circ} \mathrm{C}$ until the present study.

Case 2. The patient was a female of Japanese extraction. Born after a normal pregnancy and delivery, her birth weight was $3,200 \mathrm{~g}$. She was the second child of unrelated healthy parents. Her elder brother had died at 2 weeks of age with severe vomiting. She showed normal development until 2 years of age, when the first episode of intermittent vomiting was observed. Because of repeated periodic vomiting accompanying anorexia, lethargy and inappropriate behavior, the patient was admitted to hospital at 8 years of age. On admission, the serum ammonia level was $250-260 \mu \mathrm{g} / \mathrm{dl}$ and blood nitrogen $6 \mathrm{mg} / \mathrm{dl}$. Serum amino acid analysis disclosed an elevated level of glutamine 1,450 $\mu \mathrm{mol} /$ liter (normal, 325-467 $\mu \mathrm{mol} /$ liter), associated with normal levels of other amino acids. Urinary orotic acid was elevated to $197 \mu \mathrm{g} / \mathrm{mg}$ creatinine (control below $6 \mu \mathrm{g} / \mathrm{mg}$ creatinine). Extremely low OCT activity and normal activities of other urea cycle enzymes were found in biopsied liver tissue. At 10 years 5 months of age, the patient died coma after severe hyperammonemia lasting for 6 days. The postmortem liver sample was stored at $-80^{\circ} \mathrm{C}$ until the present analysis.

Case 3. The patient was the first female child of unrelated healthy Japanese parents. Born after an uncomplicated pregnancy of 40 weeks, her birth weight was $3,450 \mathrm{~g}$. Her elder brother, who was the first child of the family, had died in coma at 3 days of life. The patient developed normally until $21 / 2$ years of age, when she developed an episode of vomiting and lethargy lasting several days. Because of repeated epidodes of one or two times per month, she was admitted to hospital at 2 years 10 months of age. Her serum ammonia level was $152 \mu \mathrm{g} / \mathrm{dl}$ and urinary orotic acid $227.5 \mu \mathrm{g} / \mathrm{mg}$ creatinine. Treatment with a protein restricted diet and oral administration of sodium benzoate $(200 \mathrm{mg} /$ day) resulted in normal develop-

Jpn. J. Human Genet. 
ment associated with subnormal levels of serum ammonia and urinary orotic acid. At 5 years 6 months of age, she died in coma with severe hyperammonia after respiratory tract infection. A liver specimen obtained at autopsy was stored at $-80^{\circ} \mathrm{C}$ until the present study. The diagnosis of OCT deficiency was made at the time of the first admission on the basis of the enzyme assay results for biopsied jejunal mucosa.

Case 4. This patient was the first child of healthy Japanese parents. She was born after a normal pregnancy and delivery. A sister and brother of her mother had died of unknown causes at around one and half years of age. The patient developed the first epidode of vomiting at 8 months of age, and from then the episodes of vomiting at 8 months of age, and from then the episodes occurred frequently. At 1 year 4 months of age she was admitted to hospital because of a severe attack of vomiting and lethargy. Until this time her development was completely normal. Her serum ammonia was $385 \mu \mathrm{g} / \mathrm{dl}$ and urinary orotic acid 414 $\mu \mathrm{g} / \mathrm{mg}$ creatinine. Amino acid analysis disclosed elevated serum glutamine and glutamic acid levels. At 1 year 9 months of age a percutaneous liver biopsy was carried out to obtain a diagnosis. Treatment with a low protein diet and sodium benzoate appeared to be effective for controlling serum ammonia within the normal range.

\section{METHODS}

Measurement of OCT activity. The enzyme was extracted from the liver with cetylmethylammonium bromide solution and assayed by Brown and Cohen's method at pH 8.5 (Brown and Cohen 1959). The apparent $K_{\mathrm{m}}$ (Michaelis-Menten kinetics) of the enzyme was also determined, when enough enzyme activity or sample material was available. L-Ornithine hydrochloride and carbamoylphosphate were obtained from Sigma Chemical Co.

Immunochemical assay of OCT protein. Human liver OCT was purified by a modification of the method of Kalousec et al. (1978). The detailed procedure for the enzyme purification and preparation of anti-human OCT rabbit antibody, and the specificity of the prepared antibody were reported previously (Nagata et al., 1983). Ouchterlony double immunodiffusion was performed on a glass slide in $1 \%$ agarose, $20 \mathrm{~mm}$ potassium phosphate buffer $(\mathrm{pH} 7.0), 0.15 \mathrm{M} \mathrm{NaCl}$ and $3 \mathrm{~mm}$ sodium azide. After diffusion for 1 day at room temperature the agar was washed, dried and stained with Amido Black 10B, and then destained. Radial immunodiffussion was performed in a plastic vessel in $1 \%$ agarose, $20 \mathrm{~mm}$ potassium phos-

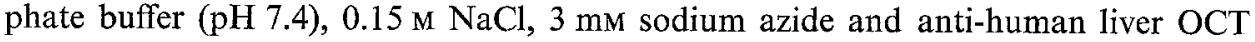
antiserum $(50 \mathrm{mg} /$ liter of immunoglobulin fraction). After diffusion for 4 days at room temperature the agar was treated as described above. The amount of enzyme protein was estimated from the diameter of the precipitin circle on radial immunodiffusion and expressed as $\%$ of control liver OCT. 


\section{RESULTS}

The results obtained are shown in Table 1. OCT from the male patient (case \#1) showed extremely depressed activity and no immunologically cross-reactive material (CRM) against anti-human OCT antibody. In female patients some variations were observed in the enzyme activity and also in the amount of CRM. Of them, two samples from cases $\# 2$ and $\# 3$ revealed close findings as to the enzyme activity, amounting to 9.2 and $8.0 \%$ of the control, respectively. The kinetic parameters and amounts of CRM were also similar in these two samples. These $K_{\mathrm{m}}$ values were identical to those of the normal control. On the other hand, in a sample obtained from case \#4, a female patient, the enzyme activity was $22.5 \%$ of the control, while the amount of CRM was $48.5 \%$ of the control. On the double immunodiffusion plate (Fig. 1), a precipitin band against the prepared antibody was

Table 1. Ornithine carbamoyltransferase (OCT) in liver tissue. Enzyme activity, kinetics and amount of immunologically cross-reactive material (CRM) in patients with OCT deficiency.

\begin{tabular}{|c|c|c|c|c|}
\hline Patient & $\begin{array}{c}\text { Activity } \\
(\mu \mathrm{mol} / \mathrm{hr} / \mathrm{mg} \text { protein })\end{array}$ & $\begin{array}{l}K_{\mathrm{m}} \text { for } \\
\text { ornithine }\end{array}$ & $\begin{array}{c}K_{\mathrm{m}} \text { for } \\
\text { carbamoylphosphate }\end{array}$ & $\begin{array}{l}\text { CRM } \\
\% \text { of control }\end{array}$ \\
\hline Case 1 (male) a & 0.2 & ND & $\mathrm{ND}$ & negative \\
\hline Case $2(\text { female })^{a}$ & 3.7 & 0.83 & 0.2 & 10 \\
\hline Case 3 (female) $^{a}$ & 3.2 & 0.75 & 0.2 & 10 \\
\hline Case 4 (female) $^{b}$ & 9.0 & ND & ND & 48.5 \\
\hline Control $(\mathrm{N}=5)$ & $40 \pm 8.0$ & $0.6-0.8^{\mathrm{c}}$ & $0.12-0.2^{\mathrm{c}}$ & 100 \\
\hline
\end{tabular}

a Autopsied sample. b Biopsied sample. c Cited from previous reports (Nagata et al., 1980, 1983). ND: not determined.

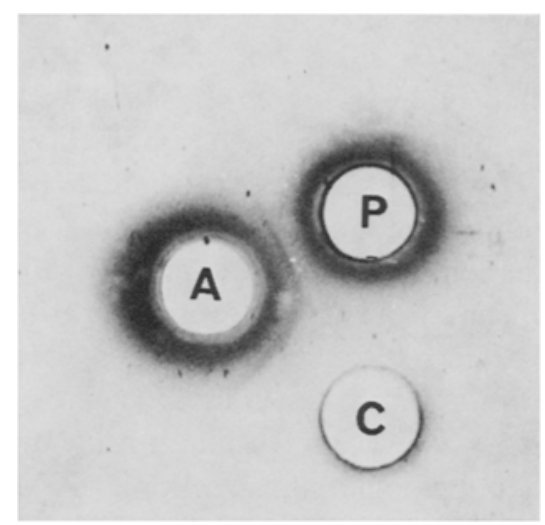

Fig. 1. Ouchteriony double immunodiffusion of the crude human liver homogenate. $A$, anti-human liver OCT antibody; $P$, patient liver homogenate (case \#4) (protein, $100 \mu \mathrm{g}$ ); C, control liver homogenate protein (protein, $48 \mu \mathrm{g}$ ). 
visible in the patient's liver homogenate sample (100 $\mu \mathrm{g}$ of protein) being similar to the result for a half amount of the control sample ( $48 \mu \mathrm{g}$ of protein).

\section{DISCUSSION}

Most studies carried out so far were attempts to clarify the heterogeneity of mutant OCT according to the kinetic characteristics (Matsuda et al., 1971; Cathelineau et al., 1974; Sinatora et al., 1975; Snodograss, 1981). Francois et al. (1982) and Mori et al. (1980) extended studies on mutant OCT analysis by use of an immunochemical method. They prepared anti-mouse and/or bovine OCT antibodies, since the enzyme from both animals shared a common antigenicity with a human OCT. It was observed that, when these antibodies were used to determine the amount of CRM in liver tissue of affected patients, there were occasionally considerable discrepancies between the obtained results as follows; some mutant enzymes react with anti-bovine OCT antibody but not with anti-mouse OCT antibody, and on the contrary, a completely reverse situation was also observed for other mutant enzymes (Francois et al., 1982). This observation suggests that there are some problems in assuming gene abnormalities through these studies and the use of anti-human OCT antibody is the most desirable. To our knowledge, the present study is the first attempt at using the anti-human OCT antibody for detecting the biochemical heterogeneity of mutant OCT. The first case, a male patient, showed a rapid course of the illness and extremely low enzyme activity associated with negative CRM, suggesting that the mutation caused a quantitative reduction of enzyme protein production or synthesis of a distinctly unstable enzyme. It was shown by histochemical techniques that female individuals, heterozygous for OCT deficiency, had two different populations of hepatocytes with apparently normal or no OCT activity (Ricciuti et al., 1976). Once an X-chromosome is inactivated during embriogenesis, it rarely, if ever, becomes functionally activated in daughter somatic cells, as suggested by Lyon (1961). This mechanism resulted in clusters of normal and abnormal cells in heterozygotes for X-linked disorders. The second and third cases, female patients had OCT activities amounting to 9.2 and $8.0 \%$ of the control which well corresponded to the amounts of enzyme protein, $10 \% \mathrm{each}$, determined by the radial immunodiffusion method. Both $K_{\mathrm{m}}$ values for ornithine and for carbamoylphosphate were similar to those in controls in these cases. This observation may indicate that the residual enzymes in these patients are coded by the normal gene for OCT. In other words, approximately $90 \%$ of the X-chromosome carrying the normal gene for OCT might be inactivated in the liver tissue. Similar to in the first case, the mutant gene possibly caused production of a CRM negative enzyme. The fourth case, a female patient, showed approximately $22.5 \%$ of the enzyme activity and $48.5 \%$ of the enzyme protein of the control. This may indicate that the patient's liver contained a mixture of normal and mutant OCT, and the latter had no or only extremely low activity but some amount of immuno- 
reactive material. Thus, it is likely that the mutant enzyme in this patient is coded by a structural gene mutation, although further confirmation could not be made because of the limited sample. Mori et al. (1980) reported that OCT from autopsied liver of a female patient showed normal amounts of CRM and $9 \%$ of the enzyme activity. They separated OCT into two immunoreactive peaks by isoelectric focusing, of which the minor peak was enzymatically active while the major peak showed little or no activity (Mori et al., 1980). Similar to us, they assumed that a structural gene mutation of the X-chromosome may code the mutant OCT in the patient. Further study using cDNA of OCT, as was cloned by Horwich et al. (1983), will give us more detailed information on the mutant gene structure.

Acknowledgment This work was supported by a Grant from the Ministry of Health and Welfare, Japan, 1983.

\section{REFERENCES}

Brown, G.E. and Cohen, P.P. 1959. Comparative biochemistry of urea synthesis. J. Biol. Chem. 234: $1769-1774$.

Cathelineau, L., Sandubray, J.M., and Polonovski, C. 1974. Heterogeneous mutations of the structural gene of human ornithine carbamoyltransferase as observed in five personal cases. Enzyme 18: 103-113.

Francois, B., Briand, P., and Cathelineau, L. 1982. Immunological assay in 16 boys with ornithine transcarbamylase deficiency. In Urea Cycle Disease, Advances in Experimental Medicine and Biology, Vol. 153, Lowenthal, A., Mori, A., and Marescau, B., eds. Plenum Press, New York, pp. 53-62.

Horwich, A.L., Kraus, J.P., Williams, K., Kalosek, F., Konigsberg, W., and Rosenberg, L.E. 1983. Molecular cloning of the cDNA coding for rat ornithine transcarbamoylase. Proc. Natl. Acad. Sci. U.S.A. 80: $4258-4262$.

Kalousec, F., Francois, B., and Rosenberg, L.E. 1978. Isolation and characterization of ornithine transcarbamylase from normal human liver. J. Biol. Chem. 253: 3939-3944.

Lyon, M.F. 1961. Gene action in X-chromosome of the mouse (Mus musculus L.). Nature 190: 372-373.

Matsuda, I., Arashima, S., Nambu, H., Takekoshi, Y., and Anakura, M. 1971. Hyperammonemia due to a mutant enzyme of ornithine transcarbamylase. Pediatrics 48: 595-600.

McKusick, V.A. 1983. Mendelian Inheritance in Man. Catalogs of Autosomal Dominant, Autosomal Recessive, and X-linked Phenotypes, 6th ed., The Johns Hopkins Univ. Press, Baltimore, pp. 1085-1086.

Mori, M., Uchiyama, C., Miura, S., Tachibana, M., and Nagayama, E. 1980. Ornithine carbamoyltransferase deficiency: Coexistence of active and inactive forms of enzyme. Clin. Chim. Acta 104: 291-299.

Nagata, N., Akaboshi, I., Yamamoto, J., Matsuda, I., Ohtsuka, H., and Katsuki, T. 1980. Ornithine transcarbamylase (OTC) in white blood cells. Pediatr. Res. 14: 1370-1373.

Nagata, N., Endo, F., and Matsuda, I. 1983. Ornithine carbamoyltransferase (OCT) in the jejunal mucosa, as a reference of the liver OCT. Clin. Chim. Acta 134: 155-166.

Ricciuti, F.C., Gelehrter, T.D., and Rosenberg, L.E. 1976. X-chromosome inactivation in human liver: Confirmation of X-linkage of ornithine transcarbamylase. Am. J. Hum. Genet. 28: 332-338.

Shih, V.E. 1976. Hereditary urea-cycle disorders. In The Urea Cycle, Gridolia, S., Bagnena, R., and Meyer, F., eds., John Wiley \& Sons, New York, pp. 367-414. 
Sinatora, F., Yoshida, T., Applebaum, M., Hoogenarrd, J., and Sunshine, P. 1975. Abnormalities of carbamoylphosphate synthetase and ornithine-transcarbamoylase in liver of patient with Rye's syndrome. Pediatr. Res. 193: 265-275.

Snodograss, P.J. 1981. Biochemical aspect of urea cycle discrders. Pediatrics 68: 273-275.

Walser, M. 1983. Urea cycle disorders and other hereditary hyperammonemic syndromes. In The Metabolic Basis of Inherited Diseases, 5th ed., Stanbary, J.B., Wyngaarden, J.B., Fedrickson, D.S., Goldstein, J.L., and Brown, M.S., eds., McGraw-Hill, New York, pp. 402-438. 